\title{
Prescribed Burning in the Loess Hills Mixed Prairie of Southern Nebraska
}

WALTER SCHACHT AND J.STUBBENDIECK

\section{Abstract}

Abused rangelands dominated by introduced cool-season grasses and warm-season shortgrasses are common over much of the Mixed Prairie. Native decreaser species are primarily warm-season grasses and are present at only insignificant levels on abused rangeland in the Loess Hills of southcentral Nebraska. A single, latespring, prescribed fire was evaluated as a method of improvement. The study area consisted of 3 tracts of plots located on Holdrege silt loam soil (Typic Argiustall) with an average annual precipitation of $550 \mathrm{~mm}$. The vegetation on the tracts was in low range condition, with cool- and warm-season components being present in varying proportions on all tracts. In general, the dominant cool-season species were Kentucky bluegrass (Poa pratensis) and annual bromes (Bromus spp.), and the dominant warm-season specles were blue grama (Bouteloua gracilis) and buffalograss (Buchloe dactyloides). Burning reduced the basal cover and herbage yields of cool-season species. This favored the warm-season component. The increaser short grasses generally exhibited higher herbage yields and basal cover on burned as compared to unburned plots. These results indicate that a single, late-spring, prescribed burn may have a limited potential as a range improvement practice in the Loess Hills of south central Nebraska.

The Loess Hills of Southern Nebraska west of $98^{\circ} 30^{\prime}$ west longitude were described by Weaver (1965) as Mixed Prairie. The dominant native vegetation was a mixture of primarily warmseason tall, mid, and shortgrasses. Currently, over one-third of the Loess Hills is classified as native range. Due to mismanagement, approximately $60 \%$ of this rangeland (1.6 million ha) is in poor to fair range condition (Bose 1977). Improper grazing management has caused a shift in species composition from the native warmseason plant community to a mixture of warm-season shortgrasses, i.e., blue grama (Bouteloua gracilis) ${ }^{1}$ and buffalograss (Buchloe dactyloides), and undesirable cool-season grasses, i.e., Kentucky bluegrass (Poa pratensis), Canada bluegrass (Poa compressa), and annual bromes (Bromus spp.). This species composition shift results in a reduction of the quantity and quality of forage produced during the summer months.

There are numerous methods of improving rangeland in low condition, but one of the simplest and least expensive practices is prescribed burning. The ability of prescribed fires to selectively suppress or promote particular species depends primarily upon the date of the fire in relation to the phenology of the particular species. As a general rule, those species actively growing when the area is burned are much more susceptible to injury and death than dormant species or those initiating growth (Anderson et al. 1970). Fire severity, which is closely related to fuel loading, size and distribution of fuel, weather, and moisture content of soil and fuel, is also a major factor affecting fire damage to living plants (Wright and Bailey 1982). A late-spring fire has been a particularly effectve

Authors are graduate research assistant and professor (range ecology), Department of Agronomy, University of Nebraska, Lincoln 68583. Mr. Schact is currently graduate teaching assistant, Range Science Department, Utah State University, Logan 84322.

Published as Paper Number 7087, Journal Series, Nebraska Agricultural Experiment Station.

Manuscript accepted March 25, 1984.

Nomenclature follows Gould and Shaw 1983 method of controlling Kentucky bluegrass (Hensen 1923, Ehrenreich 1959, and Launchbaugh and Owensby 1978), Canada bluegrass (Curtis and Partch 1950), and Japanese brome (Bromus japonicus)(McMurphy and Anderson 1965). In many mesic areas of the Mixed Prairie, prescribed burning has been used to control cool-season grasses without reducing herbage yields or cover of warm-season grasses (Kirsch and Kruse 1972, Gartner and Thompson 1972), although total herbage yield has been reduced the first year following the burn (Dwyer and Pieper 1967).

The primary purpose of this study was to determine the potential of a single late-spring prescribed burn in one part of the Mixed Prairie as a means to shift species composition from low yielding warm-season shortgrasses and introduced cool-season grasses to species more indicative of the native Mixed Prairie vegetation, such as big bluestem (Andropogon gerardii), little bluestem (Schizachyrium scoparium), switchgrass (Panicum virgatum), and sideoats grama (Bouteloua curtipendula).

\section{Study Area}

This study was conducted in the Loess Hills of southcentral Nebraska near Harlan County Lake on land managed by the U.S. Army Corps of Engineers. Three sites (Tracts I, II, and III) of native rangeland were selected on the southern side of Harlan County Lake. Topography of the study area is characteristic of the Loess Hills with upland plains dissected by numerous waterways and streams which have produced considerable relief. All 3 tracts were located on silty range sites, classified as Holdrege silt loam (fine-silty, mixed, mesic Typic Argiustall). Average annual precipitation is $550 \mathrm{~mm}$ with nearly $80 \%$ occurring between April 1 and September 30; climate is a continental type.

All 3 of the tracts had a history of overgrazing by cattle, but had been rested the year prior to the commencement of this study. Prcliminary data, collected in August 1979, showed a high degree of variability in botanical composition between tracts of plots. Tract I was the only site which showed remnants of some of the desirable species of the Mixed Prairie, such as big bluestem, sideoats grama, and little bluestem. Tract I, however was dominated by a warm-season, shortgrass community of blue grama and buffalograss, along with Canada and Kentucky bluegrasses and western wheatgrass (Agropyron smithii). Warm-season shortgrasses were the major species in Tract $\mathrm{Il}$, although downy brome (Bromus tectorum), Japanese brome, yellow sweetclover (Melilotus officinalis) and bluegrasses were also prominent. Tract III was dominated by the cool-season species Kentucky bluegrass and western wheatgrass.

\section{Materials and Methods}

Treatments applied in this experiment were fall mowing and late-spring perscribed burning along with a control. Both of the treatments represented possible improvement practices. At each Tract, each treatment was randomly allocated to a plot within each of 3 blocks. Slope was the blocking criterion. Plots, $8 \mathrm{~m}$ wide by 15 $\mathrm{m}$ long, were arranged in a randomized complete block design.

In September 1979 and 1980, all standing vegetation on the mowed plots was clipped to a height of $5 \mathrm{~cm}$ with a sicklebar mower and clipped material was removed from the plots. Prescribed burn- 


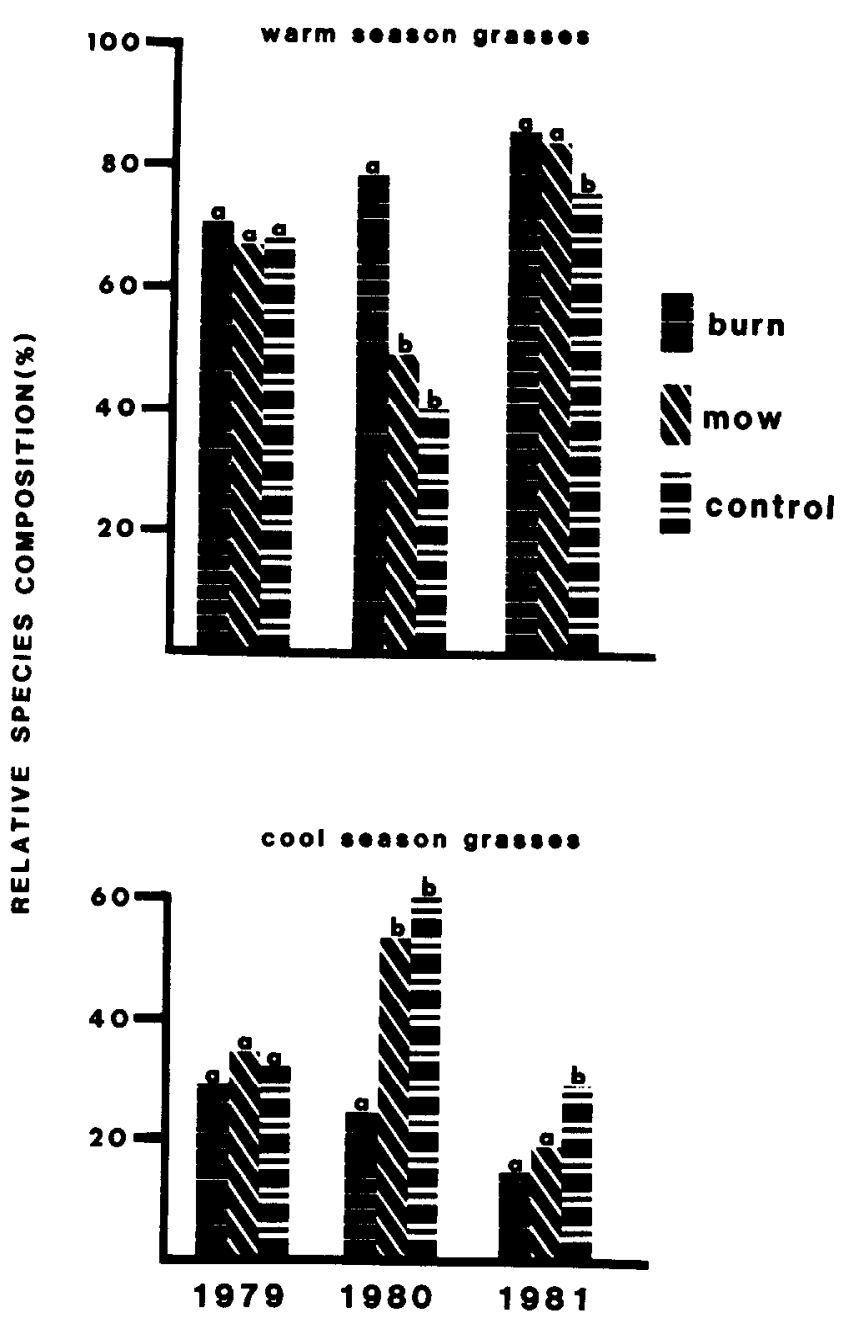

Fig. 1. Relative species composition of warm-and cool-season grasses from 1979 (before treatment) through 1981 on Tract Iin Harlan County, Neb. Bars within each year and grass group designated by the same letter not significantly different at the $10 \%$ level as determined by Duncan's multiple range test.

ing of the designated plots took place on April 25, 1980. The backfire technique was used. Approximate weather conditions during burning were $15^{\circ} \mathrm{C}$ air temperature, $30 \%$ relative humidity, 15 to $20 \mathrm{~km} /$ hour a wind speed, and $11^{\circ} \mathrm{C}$ soil temperature at a depth of $5 \mathrm{~cm}$. Fuel loads were 5,$335 ; 4,681$; and $7,533 \mathrm{~kg} / \mathrm{ha}$ on Tracts I, II, and III, respectively.

Basal cover and relative species composition was measured using a 10-point frame (Heady and Rader 1958). Readings were made in August 1979, prior to application of treatments, and again in August 1980 and 1981 using 400 points in each plot. During both the 1980 and 1981 growing seasons, herbage yields of all plots were determined during the first week in June and during the latter part of September. Four $0.3 \mathrm{~m}$ by $0.6-\mathrm{m}$ quadrats were positioned at random within each plot, and all plants were hand-clipped at ground level. Dead plant material was separated from living, and live plant material was separated by species. Samples from each plot were then dried to a constant weight at 65 to $70^{\circ} \mathrm{C}$ in a forced-air oven.

Soil moisture was determined gravimetrically 11 times during the 1980 growing season and 6 times during the 1981 growing season. Soil cores were removed at $0-15 \mathrm{~cm}, 15-30 \mathrm{~cm}$, and $30-60$ $\mathrm{cm}$ depths at numerous randomly selected locations within each
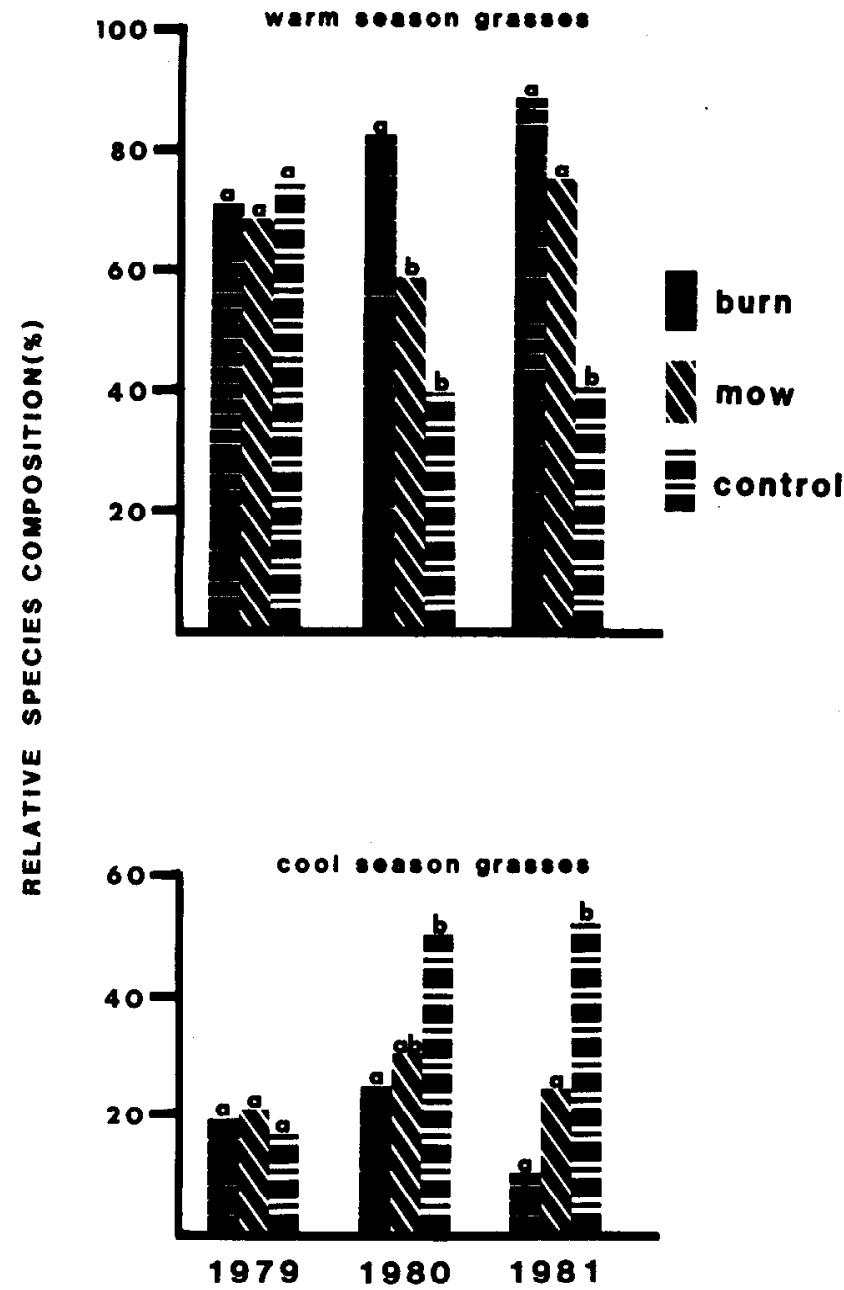

Fig. 2. Relative species composition of warm-and cool-season grasses from 1979 (before treatment) through 1981 on Tract II in Harlan County, Neb. Bars within each year and grass group designated by the same letter are not significantly different at the $10 \%$ level as determined by Duncan's multiple range test.

plot.

Each of the 3 tracts was analyzed separately since they differed initially in botanical composition. Data for the 2 years were analyzed separately, and analysis of variance was computed for each variable. Duncan's multiple range test $(p<0.1)$ was used to differentiate means (Steel and Torrie 1960). A multivariate analysis using Wilke's criterion method was used to determine changes in species composition by treatment from 1980 to 1981 (Stroup and Stubbendieck 1983).

\section{Results and Discussion}

\section{Precipitation}

Precipitation during the growing season (April through September) following the fire was only $57 \%$ of the long-term average. Desirable warm-season grasses showed moisture stress throughout much of the growing season. Precipitation during the second growing season following the fire was above the long-term average.

\section{Relative Species Composition}

Percent basal cover of 55 species was recorded on the 3 tracts. Species were grouped into the 2 major categories of warm-season grasses and cool-season grasses for purposes of analysis. Forbs were not analyzed, because they were usually only minor components. 
Relative species composition in 1980 of the cool-season grasses on the burned plots of Tracts I and II was significantly lower than that of the unburned plots (mowed and control, Fig. 1 and 2). By August 1981, relative species composition of the cool-season component on the burned plots was similar to that of the mowed plots, but the differences between the burned and control plots remained significant. Due to the suppression of the cool-season component, relative species composition of warm-season grasses was significantly higher on the burned plots of Tracts I and II than that on the mowed and control plots by August 1980 . There was no longer a significant difference between the burned and mowed treatments in 1981 , but the treated plots were significantly different from the control. Relative species composition was similar on all plots of Tract III for both years of this study (Fig. 3).

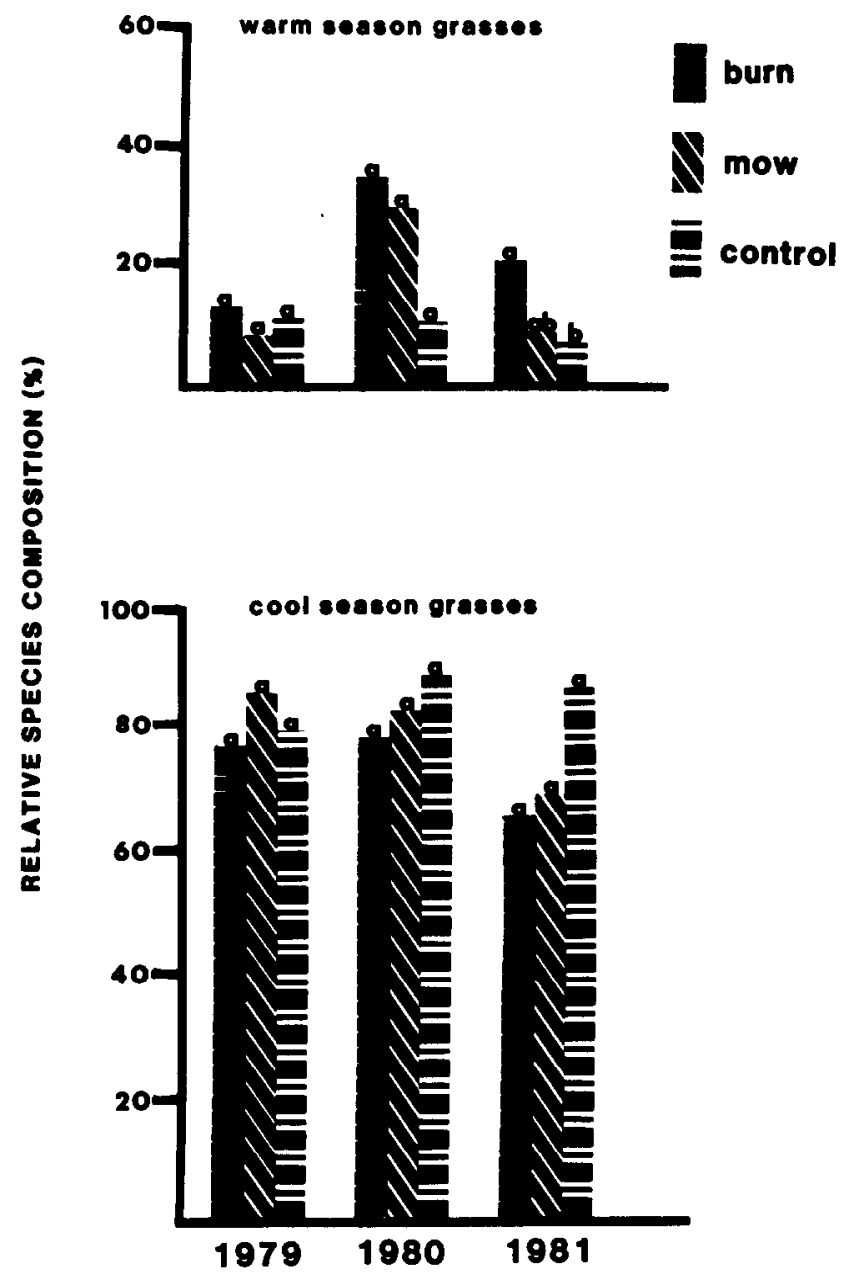

Fig. 3. Relative species composition of warm- and cool-season grasses from. 1979 (before treatment) through 1981 on Tract III in Harlan County, Neb. Bars within each year and grass group designated by the same letter are not significantly different at the $10 \%$ level as determined by Duncan's multiple range test.

For all tracts, multivariate analysis showed the aggregate species composition did not change by treatment from 1980 through 1981 . Therefore, initial treatment effects of Tracts I and II carried through to the end of the study. On Tract III, cool-season grasses remained dominant on all plots. The change in warm-season grasses on the burned and mowed plots was not significant.

Relative species composition of the cool-season grasses, Kentucky bluegrass, Canada bluegrass, and annual bromes, was generally lower on the burned plots than the unburned plots. Blue grama was the primary warm-season shortgrass which had higher basal cover on the burned plots than on the unburned plots. Basal cover of sand dropseed (Sporobolus cryptandrus), an increaser midgrass species, was also higher on the burned plots. Basal cover of decreaser species, such as sideoats grama, was not affected by either treatment.

\section{Herbage Yield}

The initial effect of the fire was to greatly suppress the herbage yield of the cool-season species on the burned plots (Tables 1, 2,

Table 1. The effect of burning, mowing, and control on herbage yields (kg/ha) of cool- and warm-season grasses (and dominant species within each group) on Tract I in Harlan County, Nebraska, for four harvest dates during 1980 and 1981.

\begin{tabular}{|c|c|c|c|c|}
\hline \multirow{2}{*}{$\begin{array}{l}\text { Date of } \\
\text { Harvest }\end{array}$} & \multirow{2}{*}{$\begin{array}{l}\text { Species Groups and } \\
\text { Dominant Species }\end{array}$} & \multicolumn{3}{|c|}{ Treatment } \\
\hline & & Burn & Mow & Control \\
\hline & & \multicolumn{3}{|c|}{$\ldots \mathrm{kg} / \mathrm{ha}$} \\
\hline \multirow[t]{7}{*}{ June 1980} & Warm-season grasses & $871 a^{1}$ & $625 b$ & $609 b$ \\
\hline & blue grama & $307 a$ & $217 \mathrm{a}$ & $276 a$ \\
\hline & sideoats grama & $152 a$ & $82 a$ & $49 \mathrm{a}$ \\
\hline & sand dropseed & $166 a$ & $82 b$ & $111 b$ \\
\hline & Cool-season grasses & $442 a$ & $1864 b$ & $1869 \mathrm{~b}$ \\
\hline & bluegrasses & $305 a$ & $890 \mathrm{~b}$ & $1549 c$ \\
\hline & annual bromes & la & $484 b$ & $132 \mathrm{a}$ \\
\hline \multirow[t]{7}{*}{ September 1980} & Warm-season species & $1578 \mathrm{a}$ & $1043 b$ & $128 \mathrm{lab}$ \\
\hline & blue grama & $741 a$ & $393 b$ & $760 a$ \\
\hline & sideoats grama & $155 a$ & $244 a$ & $160 \mathrm{a}$ \\
\hline & sand dropseed & $488 \mathrm{a}$ & $284 a b$ & $77 b$ \\
\hline & Cool-season grasses & $251 \mathrm{a}$ & $335 \mathrm{a}$ & $228 a$ \\
\hline & bluegrasses & $136 \mathrm{a}$ & $169 \mathrm{a}$ & $211 a$ \\
\hline & annual bromes & la & $3 a$ & $5 a$ \\
\hline \multirow[t]{7}{*}{ June 1981} & Warm-season grasses & $1336 \mathrm{a}$ & $979 b$ & $472 \mathrm{c}$ \\
\hline & blue grama & $635 a$ & $618 a$ & $169 \mathrm{~b}$ \\
\hline & sideoats grama & $191 \mathrm{a}$ & $123 a$ & $16 a$ \\
\hline & sand dropseed & $231 \mathrm{a}$ & $115 a$ & $75 \mathrm{a}$ \\
\hline & Cool-season grasses & $650 a$ & $819 a$ & $891 \mathrm{a}$ \\
\hline & bluegrasses & $226 a$ & $280 \mathrm{a}$ & $445 a$ \\
\hline & annual bromes & $66 a$ & $177 \mathrm{a}$ & $139 a$ \\
\hline \multirow[t]{7}{*}{ September 1981} & Warm-season grasses & $2419 a$ & $2059 a$ & $2082 a$ \\
\hline & blue grama & $694 a$ & $947 a$ & $785 a$ \\
\hline & sideoats grama & $705 a$ & $59 b$ & $274 a b$ \\
\hline & sand dropseed & $288 \mathrm{a}$ & $578 \mathrm{a}$ & $\begin{array}{r}570 a \\
515\end{array}$ \\
\hline & Cool-season grasses & $529 a$ & $912 b$ & $1151 \mathrm{~b}$ \\
\hline & $\begin{array}{l}\text { bluegrasses } \\
\text { annual bromes }\end{array}$ & $321 a$ & $506 a b$ & $960 \mathrm{~b}$ \\
\hline & annual bromes & $\mathbf{0 a}$ & $\mathbf{6 a}$ & la \\
\hline
\end{tabular}

IMeans within each species and date followed by the same letter are not significantly different at the $10 \%$ level as determined by Duncan's Multiple Range Test.

and 3). For the June 1980 harvests of Tracts I and II, herbage yield of cool-season grasses on the control plots was nearly 7 times and 4 times, respectively, greater than that on the burned plots. As with relative species composition data, herbage yield of the cool-season species on the burned plots tended to remain lower for the duration of the study. This was probably due to the increased competitiveness of the warm-season grasses. For Tract III, the initial effect of the fire was to reduce herbage yield of cool-season grasses on the burned plots (Table 3 ). The effect was short lived, as herbage yield of cool-season species was similar on all plots by the September, 1980 harvest. A substantial warm-season component was not present to take advantage of the suppression of the cool-season species.

Prescribed burning was effective in practically eliminating the annual bromes. However, by June 1981 the annual brome had invaded the burned plots (Tables 1 and 2). The bluegrasses were damaged by the effects of fire, although they were not eliminated from the burned plots. They appeared to have regained their vigor by the second year following the fire, but their herbage yields on the burned plots remained lower than those on the control plots (Tables 1 and 2).

Herbage yields of warm-season grasses of the burned plots of Tracts I and II were generally higher than that of the unburned plots for both 1980 and 1981 (Tables 1 and 2). Warm-season grasses of Tract III had similar herbage yields on all plots throughout 1980 and 1981 (Table 3). 
Table 2. The effect of burning, mowing, and control on herbage yields (kg/ha) of cool- and warm-senson grasses (and dominant species within each group) and yellow-sweetclover on Tract II in Harlan County, Nebraska, for four harvest dates during 1980 and 1981.

\begin{tabular}{|c|c|c|c|c|}
\hline \multirow{2}{*}{$\begin{array}{l}\text { Date of } \\
\text { Harvest }\end{array}$} & \multirow{2}{*}{$\begin{array}{c}\text { Species Groups and } \\
\text { Dominant Species }\end{array}$} & \multicolumn{3}{|c|}{ Treatment } \\
\hline & & Burn & Mow & Control \\
\hline \multirow{6}{*}{ June 1980} & & & $-\mathrm{kg} / \mathrm{ha}$ & - \\
\hline & $\begin{array}{l}\text { Warm-season grasses } \\
\text { blue grama } \\
\text { buffalograss }\end{array}$ & $\begin{array}{l}675 \mathrm{a}^{1} \\
204 \mathrm{a} \\
134 \mathrm{a}\end{array}$ & $\begin{array}{l}517 \mathrm{ab} \\
198 \mathrm{a} \\
241 \mathrm{a}\end{array}$ & $\begin{array}{l}386 \mathbf{b} \\
157 \mathbf{a} \\
113 \mathbf{a}\end{array}$ \\
\hline & sand dropseed & $101 a$ & $20 \mathrm{a}$ & $39 a$ \\
\hline & $\begin{array}{l}\text { Cool-season grasses } \\
\text { bluegrasses }\end{array}$ & $297 a$ & $1196 a b$ & $20.34 b$ \\
\hline & $\begin{array}{l}\text { bluegrasses } \\
\text { annual bromes }\end{array}$ & $\begin{array}{r}118 a \\
96 a\end{array}$ & $302 a$ & $123 \mathrm{a}$ \\
\hline & Yellow sweetclover & $107 a$ & $1044 \mathrm{ab}$ & $\begin{array}{l}1895 b \\
2855 b\end{array}$ \\
\hline \multirow[t]{8}{*}{ September 1980} & Warm-season grasses & $1242 \mathrm{a}$ & $956 \mathrm{ab}$ & $491 \mathrm{~b}$ \\
\hline & blue grama & $461 \mathrm{a}$ & $374 a b$ & $102 b$ \\
\hline & buffalograss & $307 \mathfrak{a}$ & $347 a$ & $223 a$ \\
\hline & sand dropseed & $157 a$ & $202 a$ & $112 a$ \\
\hline & Cool-season grasses & $125 \mathrm{a}$ & $106 a$ & $240 \mathrm{~b}$ \\
\hline & bluegrasses & $39 a$ & $3 \mathrm{la}$ & $86 a$ \\
\hline & annual bromes & $\mathbf{0 a}$ & $57 \mathrm{ab}$ & $142 b$ \\
\hline & Yellow sweetclower & $\mathbf{0 a}$ & $\mathbf{0 a}$ & $\mathbf{0 a}$ \\
\hline \multirow[t]{8}{*}{ June 1981} & Warm-season grasses & $1018 a$ & $837 \mathbf{a}$ & $215 b$ \\
\hline & blue grama & $549 a$ & $290 \mathrm{ab}$ & $85 b$ \\
\hline & buffalograss & $152 a$ & $235 a$ & $77 a$ \\
\hline & sand dropsed & $84 a$ & $83 a$ & $39 a$ \\
\hline & Cool-season grasses & $1271 \mathrm{a}$ & $1473 a$ & $2292 a$ \\
\hline & bluegrasses & $104 a$ & $236 a b$ & $507 \mathrm{~b}$ \\
\hline & annual brome & $1037 a$ & $1085 a$ & $1778 a$ \\
\hline & Yellow sweetclover & $1 \mathrm{a}$ & $4 a$ & $7 \mathbf{a}$ \\
\hline \multirow[t]{8}{*}{ September 1981} & Warm-season grasses & $2521 a$ & $2617 a$ & $1441 b$ \\
\hline & blue grama & $1296 \mathrm{a}$ & $876 \mathrm{~b}$ & $525 b$ \\
\hline & buffalograss & $367 a$ & $496 a$ & $138 \mathrm{ab}$ \\
\hline & sand dropseed & $415 a$ & $498 \mathrm{a}$ & $465 \mathrm{a}$ \\
\hline & Cool-season grasses & $343 a$ & $236 a$ & $1203 b$ \\
\hline & bluegrasses & $181 \mathrm{a}$ & $76 a$ & $707 a$ \\
\hline & annual brome & $113 a$ & $93 \mathbf{a}$ & 405a \\
\hline & Yellow sweetclover & $12 \mathrm{a}$ & $12 \mathrm{a}$ & $10 \mathrm{a}$ \\
\hline
\end{tabular}

${ }^{1}$ Means within each species and date followed byt the same letter are not significantly different at the $10 \%$ level as determined by' Duncan's Multiple Range Test.

Table 3. The effect of burning, mowing, and control and herbage yields (kg/ha) of cool- and warm-season grasses (and dominant species within each group) on Tract III in Harlan County, Nebraska, for four harvest dates in 1980 and 1981.

\begin{tabular}{|c|c|c|c|c|}
\hline \multirow{2}{*}{$\begin{array}{l}\text { Date of } \\
\text { Harvest }\end{array}$} & \multirow{2}{*}{$\begin{array}{c}\text { Species Groups and } \\
\text { Dominant Species }\end{array}$} & \multicolumn{3}{|c|}{ Treatment } \\
\hline & & Burn & Mow & Control \\
\hline & & & $-\mathrm{kg} / \mathrm{ha}$ & \\
\hline \multirow[t]{4}{*}{ June 1980} & $\begin{array}{l}\text { Warm-season grasses } \\
\text { sand dropseed }\end{array}$ & $\begin{array}{l}77 a^{1} \\
76 a\end{array}$ & $\begin{array}{r}119 a \\
17 a\end{array}$ & $\begin{array}{l}46 a \\
27 a\end{array}$ \\
\hline & Cool-season grasses & $665 a$ & $1626 a b$ & $1933 b$ \\
\hline & bluegrasses & $423 a$ & $1161 \mathrm{ab}$ & $1833 \mathrm{~b}$ \\
\hline & western wheatgrass & $238 a$ & $432 \mathrm{a}$ & $100 a$ \\
\hline \multirow[t]{5}{*}{ September 1980} & Warm-season grasses & $595 \mathrm{a}$ & $403 a$ & $631 \mathrm{a}$ \\
\hline & sand dropseed & $476 a$ & 370a & $599 a$ \\
\hline & Cool-seasan grasses & $577 a$ & $568 \mathrm{a}$ & $482 a$ \\
\hline & bluegrasses & $371 \mathbf{a}$ & $225 a$ & $367 a$ \\
\hline & western wheatgrass & $206 a$ & $324 a$ & $112 a$ \\
\hline \multirow[t]{5}{*}{ June 1981} & Warm-season grasses & $213 a$ & $49 b$ & $28 \mathrm{~b}$ \\
\hline & sand dropseed & $176 a$ & $47 b$ & $5 b$ \\
\hline & Cool-season grasses & $1733 a$ & $1577 \mathrm{a}$ & $1867 \mathrm{a}$ \\
\hline & bluegrasses & $-908 \mathrm{a}$ & $1222 a$ & $1620 \mathrm{a}$ \\
\hline & western wheatgrass & $765 a$ & $342 a$ & $196 a$ \\
\hline \multirow[t]{4}{*}{ September 1981} & Warm-season grasses & $1433 a$ & $1263 a$ & $1340 \mathrm{a}$ \\
\hline & sand dropseed & $882 a$ & $642 a$ & $623 a$ \\
\hline & Cool-season grasses & $1618 a$ & $1981 a$ & $1961 \mathrm{a}$ \\
\hline & $\begin{array}{l}\text { bluegrasses } \\
\text { western wheatgrass }\end{array}$ & $\begin{array}{r}1121 a \\
478 a\end{array}$ & $\begin{array}{r}1283 a \\
693 a\end{array}$ & $\begin{array}{r}1882 \mathrm{a} \\
79 \mathrm{a}\end{array}$ \\
\hline
\end{tabular}

Means within each species and date followed by the same letter are not significantly different at the $10 \%$ level as determined by Duncan's Multiple Range Test.
There was an apparent absence of substantial remnants of midand tallgrasses on all tracts. The only decreaser species that showed significantly higher herbage yields on the burned plots than on the unburned plots was sideoats grama. This took place on Tract I for the September harvest following the relatively wet growing season of 1981 . The prominent warm-season shortgrasses took advantage of the reduced level of the cool-season species, and increased in abundance. Blue grama was the principal warm-season shortgrass that showed significantly higher herbage yields on the burned as compared to the control plots (Table 2). Blue grama is more drought resistant than buffalograss, the other relatively abundant shortgrass on the site. Therefore, during the initial dry growing season, blue grama was better able to quickly reproduce vegetatively after the fire. Sand dropseed exhibited significantly high herbage yields on the burned plots of Tract I following the fire (Table 1). It is a prolific seed producer that is one of the first species to establish on denuded rangeland, and is drought resistant.

Total herbage yields on the burned plots of the 3 tracts were generally one-half of that on the unburned plots for the June 1980 harvest (Tables 1,2, and 3). For the following 3 harvests, the total herbage yields were similar on all plots of each tract. Warm-season grasses comprised a greater portion of this total herbage yield on the burned plots of Tracts I and II than on the unburned plots of these tracts. Composition of the total herbage yield of Tract III was similar for all plots.

The mowing treatment was not nearly so effective as the burn treatment in respect to causing significantly higher yields of warmseason grasses. This was due partly to its ineffectiveness in consistently suppressing cool-season grasses (Tables 1, 2, and 3). Therefore, herbage yields and relative species composition of the mowed plots were similar to those of the control plots.

\section{Soil Moisture}

During the first 2 months following the prescribed burning, soil moisture of the burned plots tended to be higher than that of the unburned plots. This was probably due to the reduced amount of cool-season plant growth on the burned plots. Following this initial period, the soil moisture of the mowed and burned plots was generally lower than that of the control plots. The control plots were well insulated with a cover of litter, whereas the treated plots had most of their above-ground biomass removed by burning or by mowing and raking.

Initial suppression of the cool-season grasses on the burned plots normally led to significantly higher herbage yields and basal cover of warm-season grasses. Warm-grasses were better able to compete with the fire-damaged, cool-season grasses. Also, with the reduction of the cool-season component during the first part of the $\mathbf{1 9 8 0}$ growing season, the soil moisture of the burned plots was relatively high at the time warm-season grasses initiated growth.

The type of warm-season species encouraged by the effects of fire depended upon the composition of the prefire, warm-season vegetation. On Tract III there were few remnants of any warm-season grasses. As a result, increases in herbage yields and basal cover of less desirable warm-season, increaser and invader species became significant. Tracts I and II had substantial populations of warmseason shortgrasses, and therefore, herbage yields and cover of shortgrasses increased significantly. Remnant populations of decreaser, warm-season mid and tallgrasses were present on Tract I, but they did not increase to a prominent level. This group may have shown higher herbage yields and cover on the burned plots if $1980 \mathrm{had}$ been an average to wet year. Instead, due to the very dry 1980 growing season, the shortgrasses and less desirable midgrasses were better able to compete than the decreaser, mid and tallgrasses.

Fall mowing proved to be an ineffective method of producing the desired species composition shift within the time allowed by this study. The mow treatment failed to significantly affect the relative composition of the dominant species.

It appears that prescribed burning in the form of a single, late- 
spring fire has a limited potential as an improvement practice on abused rangeland in the Loess Hills. A species composition shift from the low-yielding, warm-season shortgrasses and introduced cool-season species to the native mid and tallgrasses is dependent upon the presence of remnants of these decreaser species. The abused rangeland in this study had few remnants present and the desired shift was not obtained.

\section{Literature Cited.}

Anderson, K.L., E.F. Smith, and C.E. Owensby. 1970. Burning bluestem range. J. Range Manage. 23:81-92.

Rose; D:R: 1977. Rangelands resources of Nebraska. Soc. Range Manage., Ok West Regional Range Program and United States Dep. Agr. Soil Conserv、 Service, Lincoln, Neb.

Curtis, J:T., and M.L. Partch. 1950. Some factors affecting flower stalk production in Andropogon gerardi. Ecology. 31:488-489.

Dwyer, D.D., and R.D. Pieper. 1967. Fire effects on blue grama-pinyonjuniper rangeland in New Mexico. J. Range Manage. 20:359-362.

Ehrenreich, J.H. 1959. Effect of burning and clipping on growth of native prairie in lowa. J. Range Manage. 12:133-137.

Gartner, F.R., and W.W. Thompson. 1972. Fire in the Black Hills forestgrass ecotone. Proc. Tall Timbers Fire Ecol. Conf. 12:37-68.
Gould, F.W., and R.B. Shaw. 1983. Grass systemics. Texas A\&M Univ. press. College Station.

Heady, H.F., and L. Rader. 1958. Modifications of the point frame. J. Range Manage. 11:95-96.

Hensen, R.L. 1923. Recent studies on the effect of burning on grassland vegetation. Ecology. 4:183-188.

Kirseh, L.M., and A.D. Kruse. 1972. Prairie fires and wildlife. Proc. Tall Timbers Ecol. Conf. 12:289-303.

Launchbaugh, J.L., and C.E. Owensby. 1978,Kansas rangelands: their management based on half a century of research. Kansas Agr. Exp. Sta., Bull. 622.

MeMurphy, W.E., and K.L: Anderson, 1965. Burning Flint Hills range. J, Range Manage. 18:265-269.

Steel, R.G.D., and J.H. Torrie. 1960. Principles and procedures of statistics. McGraw-Hill Book Co., New York.

Stroup, W.W., and J.Stubbendieck. 1983. Multivariate statistical methods to determine changes in botanical composition. J. Range Manage. 36:208-212.

Weaver, J.E. 1965. Native vegetation of Nebraska. Univ. of Nebraska Press, Lincoln, Nebraska.

Wright, H.A., and A.W. Bailey. 1982. Fire ecology. John Wiley \& Sons. New York. 